

\title{
The curious case of legal translation ${ }^{1}$
}

\author{
E. Cornelius \\ Department of Linguistics \& Literary Theory \\ University of Johannesburg \\ JOHANNESBURG \\ E-mail: eleanorc@uj.ac.za
}

... legal translation serves as a bridge for understanding between nations, facilitating the resolution of vital human issues. Such a significant tool deserves broader recognition from both linguists and jurists alike.

(Rotman, 1995-1996:196.)

\section{Abstract \\ The curious case of legal translation}

This article explores the nature and scope of legal translation which is an under-researched area in South Africa. In this article the author predicts that the demand for competent legal translators will increase in the future, evidenced by a recent call by the Department of Justice and Constitutional Development (DoJ\&CD), inviting applications for ten positions for "legislative language practitioners". However, legal translation differs substantially from general translation in the sense that legal translation is subject to heavy restrictions at all levels and legal considerations are of paramount importance in a country such as South Africa, which provides for eleven official languages. Legal translation involves different legal languages, different legal systems and different cultural systems that require spe-

1 Although the main focus of this article is on the translation of legislation, the term legal translation is used throughout, as is the case in the literature. Cao (2007:8) distinguishes between main categories and sub-categories of legal texts, such as legislative texts which include national and provincial legislation, bylaws, ordinances, et cetera; judicial texts which are written by judicial officials and other authorities as part of the judicial process; academic texts or metatexts, which are descriptive texts about the law, such as textbooks and books on legal topics; and private legal texts, such as contracts, wills, letters of demand, lease agreements, et cetera. The term legal translation is used in its widest sense to refer to the translation of all four categories of legal texts. 
cialised knowledge and skills of the translator. The aim of this article is to investigate the core competencies and skills the legal translator must have; to consider the balance between legal competence and translation or linguistic competence; and to propose a discourse-analytical method of source text analysis, developed by Bhatia as a simplification strategy, as this may be a powerful tool in the training of legal translators in South Africa. Recent developments in South Africa relating to the Department of Arts and Culture's obligation to translate legislation into all official languages, have important consequences for legal translation in general and the training of legal translators in particular.

\section{Opsomming}

\section{Die unieke uitdagings van regsvertaling}

Hierdie artikel verken die aard en omvang van regsvertaling, 'n studiegebied waaroor min navorsing in Suid-Afrika gedoen is. In hierdie artikel voorspel die outeur dat die vraag na bevoegde regsvertalers in die toekoms gaan toeneem. Dit word bevestig deur 'n onlangse oproep deur die Departement van Justisie en Staatkundige Ontwikkeling (DoJ\&CD) vir aansoeke vir tien "legislative language practitioner"-poste. Regsvertaling verskil egter grootliks van algemene vertaling in die opsig dat regsvertaling aan swaar beperkings op alle vlakke onderhewig is en regsoorwegings van deurslaggewende belang is in 'n land soos Suid-Afrika wat vir elf amptelike landstale voorsiening maak. Daarbenewens sluit regsvertaling verskillende regstale, regstelsels en kulturele stelsels in wat gespesialiseerde kennis en vaardighede van die vertaler vereis. Die doel van hierdie artikel is om die kernvaardighede en -vermoëns waaroor die regsvertaler moet beskik, te ondersoek; die balans tussen regsvaardigheid en vertaal- of taalvaardigheid te oorweeg; en 'n diskoersontledingsmodel vir bronteksontleding voor te stel wat deur Bhatia as ' $n$ vereenvoudigingstrategie ontwikkel is en wat 'n kragtige hulpmiddel kan wees in die opleiding van regsvertalers in Suid-Afrika. Onlangse ontwikkelings in Suid-Afrika wat die Departement van Kuns en Kultuur die verpligting oplê om wetgewing in alle amptelike landstale te vertaal, het belangrike implikasies vir regsvertaling in die algemeen en vir die opleiding van regsvertalers in die besonder.

\section{Introduction}

As a result of globalisation, the demand for well-trained and competent legal translators will increase in future (Obenaus, 1995; Sarčević, 1997; 2000; Asensio, 2003; Llopis, 2007). Indeed, as Šarčević (1997:1) points out: 
In our era of multilingualism, translation plays a major role as a medium of communication in municipal, supranational, and international law.

According to Alcaraz and Hughes (2002:2) job opportunities for translators are driven by market trends.

International organizations and institutions, government departments and agencies, multinational corporations, import-export firms, the media, the film and tourist industries, information technology and the vast web of activities of every kind spun by the Internet all provide opportunities for translators.

As a case in point, the Department of Justice and Constitutional Development (DoJ\&CD) recently advertised ten positions for "legislative language practitioners" for each of the official languages of South Africa, excluding English. Among other duties, the primary task of such a legislative language practitioner is to "translate legislation from English into other official languages in accordance with instructions issued by State departments and guidelines issued by Parliament and the Cabinet" (DoJ\&CD, 2009).

However, legal translation is a highly specialised form of translation that has received little, if any, attention in translation theory discourses and at tertiary institutions in South Africa. Courses and modules in legal translation at institutions of higher learning are extremely limited and mostly do not adequately address the demand referred to above. The questions where suitable candidates for these vacant positions will be recruited from and what the nature of their training should be now arise. If satisfactory answers to these questions are not found, South African universities in general, and departments of applied linguistics in particular, may be compelled to redesign their qualifications and modules in order to meet this market demand by supplying suitably trained and competent legal translators in all the official languages of South Africa.

The High Court ruling of 16 March 2010 (Lourens v President van die Republiek van Suid Afrika en Andere (49807/09) [2010]), forcing the Department of Arts and Culture to comply with its obligation to regulate and monitor the use of all official South African languages, further underscores the increasing demand for legal translators in all the official languages. In terms of the judgement, the Minister of Arts and Culture is given two years to honour the constitutional obligation in this regard. This will no doubt have far-reaching implications for the profession, and for the provision of translation and interpreting services, since special mention was made in the judgement of the 
obligation to translate national legislation into all eleven official languages, subject to the provisions of section 6(4) of the Constitution.

The aim of this article is to explore the field of legal translation by reviewing international literature on the topic, specifically focusing on the nature and scope of legal translation, and the core competencies of the legal translator. In addition, the importance of an analysis of the legal source text is highlighted and a method is proposed for simplifying the seemingly complex rhetorical structure of legislative provisions for translation purposes. This method is suggested as a useful tool in the training of legal translators who lack sophisticated knowledge of or formal training in law.

\section{The nature and scope of legal translation}

A recent publication on this topic defines legal translation as "the rendering of legal texts from the SL into the TL" (Cao, 2007:10). ${ }^{2} \mathrm{At}$ first glance this definition seems to be overly simplistic and inadequate in its reference to legal texts, as it seems merely to serve to distinguish legal translation from other forms of translation. As will become clear in this article, the reference to legal texts, as an umbrella term, is insufficient in view of the fact that legal instruments are extremely varied in their authority, function, legal status and legal consequences.

Some older definitions are more comprehensive in the sense that mention is made of the translation process and translation strategy, but these definitions are still lacking in providing an accurate and clear description of what legal translation entails. Schwarz (1977:21) includes the notion of equivalence and attempts to bring in some legal consideration, e.g. legal relevance.

The translator's main task in translating legal documents is to translate a text as precisely as possible. He has to find linguistic equivalents which in their legal relevance correspond to both the original text of the source language and the translated text of the target language.

Newmark (1981:47) views legal translation as a special case with tremendous limitations: "Legal documents require a special type of translation, basically because the translator is more restricted than in any other form."

2 SL and TL are abbreviations for "source language" and "target language" respectively. 
On the one hand, these definitions bring to the fore the precision and accuracy required by legal texts. On the other hand, legal translation is singled out as a form of translation that is subject to profound semiotic restrictions at all levels, from the macro- to the microstructural levels. The fixed and standardised - often referred to as "frozen" - forms that characterise legal writing, coupled with the complex nature of legal discourse, require the use of parallel structures in the target text (Garzone, 2000:3). However, these more traditional definitions of legal translation do not take into account any cultural dimension and thus ignore the fact that law is culturedependent. Obenaus (1995:249) emphasises the close link between law and culture when he states that legal documents are "pregnant with it" (i.e. with culture). In reference to legal translation, White (1990:252) argues that

... there is no position outside of culture from which the original can be experienced or described. It is read by one of us, translated by one of us speaking to the rest of us.

Moreover, these definitions do not take cognisance of the status and function of the new text, or the translation problems caused as a direct result thereof. In regard to status, the translated text may have equal legal effect and be equally binding (Garzone, 2000:4). The primary aim of legal translation is to have available a set of parallel texts that make uniform interpretation and application in practice possible. In regard to function, the target text may perform a different function against a new cultural background, compared to the original (Obenaus, 1995:248-249). The purposes for which the translated legal texts are used may be extremely varied, ranging from informational (without having legal force), doctrinal, jurisprudential, evidentiary, conventional or legislative (Beaupré, 1987:739). It therefore follows that freer approaches to translation may indeed be possible, as in the case of informational texts with no legal validity, where the primary goal of the translation is to inform the receiver of the function of the text in the culture of the source language. Texts about the law, such as law review articles or text books, may be translated by focusing primarily on the spirit of the message, and in such instances a functionalist approach seems equally acceptable for legal translation. In other instances, strict literal approaches are required, as in the case of normative texts, which constitute the law, such as statutes, where "the translator is more constrained by the words of the positive, obligatory law" (Rotman, 1995-1996:190). 
In South Africa, all translated versions of an Act of Parliament have equal legal validity and are regarded as original documents with the same authentic status. However, in the case of any conflict, the text signed by the President prevails. The notion of legal equivalence is thus of great value in legal translation and specifically to determine translation strategy, where the legal effects of a target text are considered in addition to all the other criteria of equivalence (Garzone, 2000:5). In this regard Didier (cited by Šarčević, 1997:71) asserts that "while lawyers cannot expect translators to produce parallel texts which are equal in meaning, they do expect them to produce parallel texts which are equal in legal effect".

In addition, and in relation to the close link between the law and the cultural system in which it operates, the definitions of legal translation cited above do not acknowledge the difficulties caused by "transporting legal information from one legal system and legal language to another" (Pommer, 2008:360). Legal texts do not exist in a cultural vacuum, and this may be the single biggest source of difficulty experienced in the field of legal translation. In any legal setting one finds, in addition to the peculiarities and complexities of the language of the law, a set of beliefs, "a body of doctrine and case-law" (Beaupré, 1987:740), which must be taken into account during the translation process. Legal systems are expressions of culture. In multilingual societies with diverse cultural histories - and South Africa is a prime example of such a society - and either diverse or common legal traditions, the dilemma of translation seems insurmountable. Rotman (1995-1996:189) explains the tension in legal translation.

Although legal translation demands precision and certainty, it is bound to use abstractions, whose meanings derive from particular changing cultural and social contexts. These contexts generate a certain degree of ambiguity, which increases when the legal cultures and systems are vastly different from each other.

A particular concept may thus exist in the source culture, but not in the target culture. If a source document, for instance, originates from the United States where a jury system is in place, this incongruence may cause problems for the legal translator working in African languages. Firstly, because the translation is done in a society in which it is not a jury that reaches a verdict, but a judge or a magistrate, and secondly, because there may not be an equivalent for "jury" in the African language concerned, because the jury system is not 
used in South Africa. Alternatively, a particular concept may exist in the target culture, but with a different interpretation.

The South African legal system is clearly embedded in a particular cultural system. To illustrate the interplay between a legal system and culture, a number of examples of cultural concepts follows, all of which may cause serious translation problems if documents containing these concepts were to be translated into a foreign language. A well-known South African phenomenon that may cause translation problems in other target cultures is that of community-based savings schemes, commonly referred to as "stokvels". These schemes have been vested with legal status and legislation has been introduced that deals specifically with stokvels (South Africa, 1996). As a result, the concept may appear in many legal texts that are drafted, translated and used in contemporary South Africa. Another example is the custom of "lobola" (not entirely dissimilar to "dowry" in Asian cultures), which forms part of African customary law and is welldocumented in South African case law. The notion of "ubuntu", expressing an African view of life and one of the founding principles of the new democracy in South Africa, is another example. The same holds true for "Batho Pele". Although these culture-specific notions and concepts may not cause problems for the translator working in and from the South African languages, they provide evidence of the close link between the law and the cultural system in which it operates - a significant link with huge implications for translation.

The single biggest problem with most definitions of legal translation such as the ones cited above, is their preoccupation with the notion of equivalence, mainly focusing on word and sentence level, and their inability to deal with the text against its situational and cultural background, and to consider the importance of legal status and legal consequence. Šarčević (1997:5) suggests that "a theory for the translation of legal texts must take account of legal considerations", while "it cannot disregard basic issues of translation theory". She also acknowledges the importance of pragmatic considerations in legal translation in determining an appropriate translation strategy.

It is apparent that the complexity and multifaceted nature of legal translation presents the translation theorist with wide-ranging definitional problems. For this reason the following definition of legal translation is proposed for the purposes of this article: Legal translation is the rendering of parallel texts, which are equal in legal effect, from the SL into the TL, taking into consideration the authority, function and legal status of the translated text, as well as the 
legal system and the cultural setting within which the translated text will be read and/or used.

\section{The profile of the legal translator}

It is evident that legal translation is a complex activity that requires specialised knowledge and approaches that may, in some instances, differ in no small measure from general translation, especially in regard to the importance of legal considerations that generally do not feature in general translation. As Rotman (19951996:189) puts it: "The legal translator is more rigidly bound to specialized knowledge than the translator of everyday language or humanities."

A search of South African literature yielded hardly any information on the topic, indicating that legal translation has not received sufficient attention in South African scholarly work in general and in translation theory in particular. In this section the competencies of the legal translator are investigated as described and discussed in international literature, and salient aspects that must be considered and addressed in the training of legal translators are highlighted. This is done by exploring the legal translation task as a point of departure. In addition, new trends in contemporary legal translation elsewhere in the world are reviewed. These trends resulted in changes in the role and status of the legal translator. The salient points of the advertisement issued by the Department of Justice and Constitutional Development for legislative language practitioners to be employed in the Office of the Chief State Law Adviser in Cape Town are provided here to introduce the discussion.

The advertisement lists the following requirements (DoJ\&CD, 2009):3

- A university degree majoring in at least one of the following official languages; Sepedi, Sesotho, Setswana, Xitsonga, Tshivenda, IsiZulu, IsiXhosa, IsiNdebele, IsiSwati and Afrikaans;

- A legal background will be an added advantage;

3 This is an exact word-for-word transcription of parts of the advertisement. Any spelling, grammatical and typographical errors and inconsistencies appear in the original. 
- Knowledge of other languages coupled with a practical understanding of the law or a legal qualification will be a recommendation;

- Candidate should have been involved in either providing translation services or worked as a language practitioner in at least one of the official languages.

The following skills and competencies are outlined in the advertisement: 4

- Presentation skills;

- Language Proficiency

- Communications skills;

- Computer literacy;

- Translations skills

- Ability to work under pressure.

The duties of a legislative language practitioner include inter alia: ${ }^{5}$

- Translate legislation from English into other official languages in accordance with instructions issued by State departments and guidelines issued by Parliament and the Cabinet;

- Assist the office to develop legal terminology in other languages for use in legislation;

- Interact with PANSALB and other organizations, universities and other Language Practitioners involved in promoting the use of all official language to assist with the promotion and development of our official languages in order to make our legislation more accessible to broader South African population;

In addition to a university degree with at least one official South African language as a major subject, the advertisement contains two references to legal training, background or understanding, namely "a

4 This is an exact word-for-word transcription of parts of the advertisement. Any spelling, grammatical and typographical errors and inconsistencies appear in the original.

$5 \quad$ This is again an exact word-for-word transcription of parts of the advertisement. Any spelling, grammatical and typographical errors and inconsistencies appear in the original. 
legal background" and "a practical understanding of the law or a legal qualification". Although listed under "requirements", a legal background will be regarded as an added advantage, and a practical understanding of the law or a legal qualification will be a recommendation. Under "skills and competencies", translation skills appear in the penultimate position, with presentation skills prominently foregrounded, followed by language proficiency, communication skills and computer literacy. This advertisement raises the question of how to maintain a balance between legal competence on the one hand, and linguistic and translation competence on the other, which will inform the main argument in this article.

\subsection{The debate: legal competence versus translation competence}

A survey of the literature reveals some disagreement as to the amount, the nature and the extent of specialised knowledge required on the subject matter in question. There are those scholars who emphasise the importance of a solid foundation and training in law (e.g. Schwarz, 1977; Schroth, 1986; Beaupré, 1987; Rayar, 1990; Gémar, 1995; Rotman, 1995-1996; Kennedy, 2000). In this regard, Schwarz (1977:21) is unequivocal when he remarks:

As in all other fields of knowledge, the translation of a legal and administrative text depends on the translator's full understanding and comprehension of the subject matter in question.

Kennedy (2000:428) points out that even lawyers and judges sometimes have difficulty with the complexity and technicality of legal language and find it difficult to understand legal texts written in their own languages. Translated legal texts are often even more difficult to understand; the difficulty is often caused by the interventions of non-lawyer translators. Šarčević (1997:113) points out that "all LSP translation is interdisciplinary in nature", 6 which means the legal translator must be able to make both legal and linguistic decisions. This view presupposes competence in law and in translation. With regard to specialised terminology, Rotman (1995-1996:195) asserts that a thorough knowledge of both the source and target legal systems is required, and that legal translation "requires not only knowledge of the law in general, but also solid acquaintance with the specialized field, its doctrines, and particular models". Schroth (1986:55-56) moves beyond word and sentence level when he re-

$6 \quad$ LSP is the abbreviation for Language(s) for Special Purposes. 
fers to the notion of legal effect, namely that "... the legal translator must know how to achieve the same legal effect in the target language".

Other scholars believe that the legal translator must fully understand the legal source text, but that she/he is not required to interpret such texts in the way a lawyer would - that is, in the legal sense (Šarčević, 2000:5; emphasis - EC). Understanding of the source text is a requirement for producing a satisfactory translation. In this regard, the distinction between understanding and interpretation becomes relevant. Šarčević is at pains to warn:

While it is essential for legal translators to be familiar with the methods of interpretation used by judges [...] they themselves should refrain from interpreting the text in the legal sense. (Šarčević, 1997:91.)

With regard to legal interpretation and instances of ambiguous terms, Rek-Harrop (2010:38) agrees and asserts that the legal translator should not attempt to interpret legal uncertainty, but rather leave this task to the legal professionals.

The issue of the nature and extent of the legal competence of the translator is multifaceted and complex, and not simple to resolve. It may well be wholly impossible to find such an ideal translator (Šarčević 1997:114). Schroth (1986:65) agrees with Šarčević.

Legal translation in practice usually involves the additional difficulty that neither the lawyers nor the professional translators combine the necessary qualifications in one person. When all of those qualifications are found somewhere in a team, satisfactory results are often possible given a clear understanding of the problem.

The team idea will feature again later in this article. Cao (2007:38) maintains that "successful legal translators are found around the world, performing important legal translation tasks that are often vital to the functioning of law"; the required competence can be learned and developed, and is thus attainable.

If legal translation competence can be learned and developed, as claimed by Cao (2007), the training of legal translators becomes a pertinent issue, coupled with the need to identify effective instructional methods and strategies. Notwithstanding the distinction referred to above between the understanding of a text and the interpretation of it - the former referring to an act of cognition without any 
reflection on the part of the receiver and the latter referring to the personal involvement of the receiver - the legal translator has a duty to "express what is said in the source text" (Šarčević, 1997:92). Hjort-Pedersen and Faber (2005) investigate different teaching methodologies for LSP translation training, and they conclude that trainees should be supported in their learning process by a legal knowledge structure, which will assist them to access the "communicators' communal ground" and "rule knowledge". They conclude that this legal knowledge structure will be invaluable to the legal translator trainee in making the right pragmatic inferences (Hjort-Pedersen \& Faber, 2005:52).

\subsection{The role and status of the legal translator}

In recent decades - since the 1970s - legal translation has changed in many countries around the world, most notably in Canada and Switzerland. The translator is no longer regarded as a passive mediator who acts merely as a go-between and she/he no longer occupies a highly restricted position. The legal translator is now an active participant in the legislative process, and is regarded as a text producer in his/her own right.

However, in many countries the legal translator is not involved in drafting processes (Šarčević 1997:96). In these countries translation activities are carried out, more or less in isolation, by a translation unit or division located in some government department. In such instances, the legal translator has limited decision-making authority and decisions by legal translators pertain mostly to linguistic issues.

As mentioned above, in some parts of the world far-reaching developments in legal translation have taken place. This is the case particularly in bilingual and multilingual countries where the driving force has been the demand to elevate the status and use of minority languages or those languages that are not frequently employed for higher functions; this is also done in an effort to reduce the predominance of a particular language. Šarčević (1997) describes the case of Switzerland, where German has become the exclusive official language at the expense of French and Italian. A process called "alternate drafting" was introduced in the 1970s: a combination of drafting and translation. The final product thus consists of both original and translated sections.

More recently another process, known as "co-drafting" was initiated. This process entails the formation of a co-drafting team consisting of linguists, lawyers and subject experts to oversee all phases of the 
preliminary procedure. During the subsequent parliamentary phase, all language versions are presented, discussed, and checked by a parliamentary drafting committee. Three subcommittees, one for each of the languages, compare and verify the relevant texts against the other versions, after which the final drafts are prepared. The final texts are then presented individually to be adopted and promulgated.

Similar developments have taken place in Canada, where the translator also plays an active role in legislative drafting at federal level. Co-drafting techniques in Canada "coordinate the time and place of the production of parallel texts to varying degrees, and this makes it increasingly difficult to distinguish between the source and target texts" (Šarčević, 1997:100). In Canadian co-drafting, English and French translators are involved in all the stages of the drafting process, which means the translator becomes a co-drafter in the full sense of the word. As a result, the status of the legal translator becomes elevated. The translator as co-drafter must therefore be suitably qualified to make linguistic and legal decisions. This new role and position of the legal translator highlights the need for training in law, in general, and in legislative drafting, in particular. Other configurations of bilingual drafting methods are also possible (cf. Šarčević, 1997).

An important consequence of these joint or co-drafting methods in which translators and subject specialists work together is the idea that they should work in close proximity:

... the decision to have the translators under the same roof instead of using national translation staff encourages direct consultation among them, thus making the translation process more expedient (Šarčević, 1997:111).

This again strengthens the idea of a translation team as envisaged by Schroth (1986; see 3.1 above), combining different qualifications and with all team members participating in a single communication process.

The practice of involving translators in the legislative drafting process right from the start merits close investigation in the South African context. As pointed out in section 3.1, it is highly improbable that the required competencies and qualifications will be combined in a single person. The idea of a multi-disciplinary team consisting of linguist-translators, lawyers and subject experts may provide a solution for this problem. This does not imply that all official lan- 
guages need to be represented in the legislative team in all instances. In South Africa a bill must be tabled in Parliament in two official languages, one of which must be English, as will be explained in the following section. Once the other language in which a bill will be presented has been identified and legislative drafting commences, a linguist-translator representing that particular language may be actively involved in the drafting process from the outset. At this stage it is not clear what criteria are used to determine the other language in which the bill is prepared. If languages were to be used on a rotation basis, the development of African languages could be fostered and a tremendous contribution could be made to the development of legal terminology in these languages as well. A rotation system would afford all official languages an opportunity to be used as drafting languages and therefore as source languages, from which translations into other official languages are done, thereby elevating the status of the African languages. In this way, African languages would be employed for higher functions, which would in turn increase their visibility.

Translation into the remaining languages follows after one of the two versions of the bill is assented to and signed by the President. According to Judge Du Plessis, in the High Court judgement referred to earlier in this article, the duty to translate the bill, now an Act of Parliament, rests with the Department of Arts and Culture (Lourens $v$ President van die Republiek van Suid Afrika en Andere (49807/09) [2010]).

The changing role of the legal translator seems to coincide with shifts that have taken place in translation theory, which has seen the introduction of functional approaches to translation in which the purpose or function of the translated text as a communicative tool is foregrounded. Such functional approaches are quite distinct from the traditional linguistic theories of translation.

\subsection{Legal translation and language practice in South Africa}

In the previous dispensation, before 1994, two languages were awarded official status, namely English and Afrikaans. In line with this bilingual language policy, legislation was published in these languages exclusively.

With the arrival of the new democracy in South Africa, eleven official languages gained official status. In the judgement referred to above (Lourens v President van die Republiek van Suid Afrika en Andere (49807/09) [2010], Judge Du Plessis indicates that bills are tabled in 
Parliament in two languages, one of which must be English, as required by the Parliamentary Rules. Although a bill is prepared in two official languages, only one bill, and not multiple translations, is assented to and signed by the President. ${ }^{7}$ This concludes the legislative process.

As indicated in the introduction, there is renewed pressure on government to make legislation available in the other official languages as well. The creation of posts for legislative language practitioners may be regarded as an effort on the part of government to rectify this situation, and "to make our legislation more accessible to broader (sic) South African population" (DoJ\&CD, 2009). However, in the field of legal translation, many years of lost ground have to be made up with regard to the African languages. One of the duties of a legislative language practitioner is indeed to "assist the office to develop legal terminology in other languages for use in legislation" (DoJ\&CD, 2009). Lack of terminology in the African languages may create serious problems for the legal translator. The development of legal terminology by legislative language practitioners will unquestionably contribute to the promotion and development of the African languages, and will assist in elevating the status of these languages. If legislation were to be available in African languages, conditions would be created for the use of the indigenous languages in courts, in the public service, and in other public domains.

However, since the African languages have not received equal attention in the legal domain in South Africa, and since legal translation into or from the African languages has been extremely limited to date, it can be assumed that a tremendous amount of time and effort will have to be spent on the training and development of legislative language practitioners working in these languages. As indicated earlier, it is extremely unlikely that incumbents will have both legal knowledge and linguistic/translation knowledge combined in a single person. A starting point may be to train novice legal translators to conduct a thorough analysis of the source text in question, and this is the topic of the subsequent section. An inexperienced legal translator may experience difficulties in carrying out a source text analysis of a complex legal document, such as an Act, especially if such a translator is not trained in law. A discourse analytical method for source text analysis is proposed in this article, as

7 A review of the Acts that have come into force after 1994 reveal that, in the overwhelming majority of cases, the English version is signed by the President. 
this could potentially be a powerful tool in the training of legal translators.

In meeting all the demands of the legal translation task, it is proposed that the ideal legal translator, apart from a firm grounding in language and translation theory, must develop a legal knowledge structure. Such a knowledge structure is imperative to enable the translator to achieve the same legal effect in the target language. Trainee translators should therefore be given support in acquiring legal knowledge structures during training.

\section{Source text analysis in legal translation}

From the information provided in the advertisement and from the designation "legislative language practitioner", it is evident that these incumbents will, among other duties, translate mainly domestic legislation, and will, therefore, not be required to translate private legal texts such as contracts, wills, pleadings, agreements and the like. The importance of source text analysis and hermeneutics to the translator's activity is widely accepted (viz. Rotman, 1995-1996; Nord, 1997; Varney, 2009). Bednarek (2009:90) emphasises the importance of a meticulous analysis of the source text, which requires the translator to bear in mind that two kinds of transfer are about to take place, namely intercultural transfer and legal transfer. Such an analysis will also play a vital role in selecting an appropriate translation strategy.

For Beaupré (1987:740) the effective translation of legislation is dependent on the ability of the legal translator to apply judicial methods of interpretation. The distinction between understanding and interpretation has been discussed above. Whether or not legal interpretation is required, the translator cannot escape the requirement of understanding what is conveyed in the source text. It is accepted that the non-legally-trained translator may not be equipped with the higher order legal skills to conduct a legal interpretation of the source text, and that she/he should, therefore, refrain from any such interpretation. However, it cannot be disputed that a legislative language practitioner (read: legal translator) must carry out a meticulous analysis of the linguistic and discoursal features of the source text before she/he begins with the translation task. Hjort-Pedersen and Faber (2005:50-51) emphasise that the majority of legal texts depend on an underlying rule system that is not explicitly stated in the text. The translator needs to resort to pragmatic inference to identify any gaps in his/her knowledge system and to understand the intended meaning of the source text. According to Hjort-Pedersen 
and Faber (2005:51) trainee translators must develop long-term cognitive strategies, such as inference - based on subject matter knowledge, genre knowledge, and "co-thinking rules which may only be implicitly referred to". Understanding the rhetorical structure of the source text is an important prerequisite that will facilitate the translation task and ultimately result in a successful translation.

The trainee legal translator may be overwhelmed by the lengthy sentences and high levels of information density, the complexity of the language, the technical vocabulary, and other syntactic and discoursal features of legislative writing. Bhatia (1994:153) argues that

... legislative statements have good reasons to be what they are, and one should try to understand this genre on its own terms rather than by imposing standards of ordinary expression from the outside, as it were, on a genre which has its own specialised concerns and specific constraints under which they are written and read.

An analysis of the rhetorical structure of the genre is an indispensable tool that can help the non-lawyer translator to understand the regularities and patterns in the organisation of legislation. Bhatia (1993:115) refers to the interaction between the main provisionary clause and the various kinds of qualifications that are inserted at various syntactic openings and that are the cause of the syntactic discontinuities so characteristic of legislative provisions. Bhatia (1983a) encourages the use of this simplification strategy in courses such as English for legal academic purposes as a stimulus for a vast variety of language activities. However, Bhatia's two-part interactive cognitive structure is also a useful analytical tool for source text analysis in legal translation.

An important preparatory task that forms part of any source text analysis of legal texts, according to Rotman (1995-1996:194), is to "dissect" long legal sentences by identifying the main parts of the sentence, such as subject, object, predicate and the like, not unlike ordinary parsing in grammar, and their function in the sentence. This precedes the careful consideration of lexical items and complex word contents in their legal significance. According to Bhatia (1983a; $1983 b ; 1993 ; 1994)$, the vast majority of legislative sentences set out rights and obligations of individuals and the executive, who are tasked with their implementation. In this sense, these sentences are provisionary. Such provisionary sentences typically contain two necessary elements, namely the legal subject and the legal action. 
The legal subject is the person who is given a specific right or who has to perform particular obligations. The legal action is the statement of the right or the obligation. The legal subject and the legal action match the categories "subject" and "predicate" (Bhatia, 1983a:29).

The following example is taken from the Domestic Violence Act (1998). It contains a typical legal sentence of considerable length, consisting of no less than 101 words:

Where circumstances permit and where a Family Advocate is available, a court may, in the circumstances as may be prescribed in the Mediation in Certain Divorce Matters Act, 1987 (Act 24 of 1987), when considering an application contemplated in subsection (1), cause an investigation to be carried out by a Family Advocate, contemplated in the Mediation in Certain Divorce Matters Act, 1987, in whose area of jurisdiction that court is, with regard to the welfare of any minor or dependent child affected by the proceedings in question, whereupon the provisions of that Act apply with the changes required by the context. (South Africa, 1998: Section 5(1A).)

As indicated earlier, the translator may be overwhelmed by the length and complexity of such a legal sentence. If the translator were to identify the main provisionary clause as a first step in the process of source text analysis, the segmentation of the legislative sentence could proceed and the translation task would be less daunting. The main provisionary clause in section $5(1 \mathrm{~A})$ above, is thus "a court may cause an investigation to be carried out". The legal subject is "a court" and the legal action is "may cause an investigation to be carried out".

Apart from these two essential elements, legislative provisions also contain qualifications (Bhatia, 1994:150). Qualifications remove universal application from the legislative provision and thus promote precision and clarity. However, the insertion of multiple qualifications within a single sentence contributes to sentence length, and if such qualifications are not placed carefully in the syntax of the legislative sentence, they may cause ambiguity. So, qualifications are inserted next to the word they qualify, which may result in clumsy and convoluted sentence construction and consequently contribute to sentential complexity. The main provisionary clause consists of ten words only; this means the remaining 91 words are meant to provide the "essential flesh" in the form of qualifications. These qualifications are varied in terms of the information they provide. The legislative 
sentence in section $5(1 \mathrm{~A})$ can thus be analysed in the following way, in terms of Bhatia's two-part interactive rhetorical structure:

PROVISIONARY CLAUSE

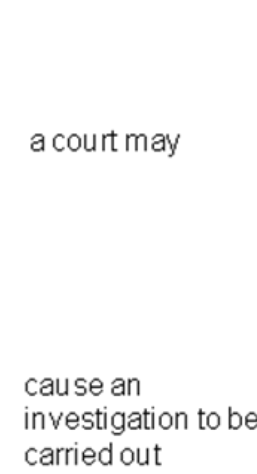

QUALIFICATIONS

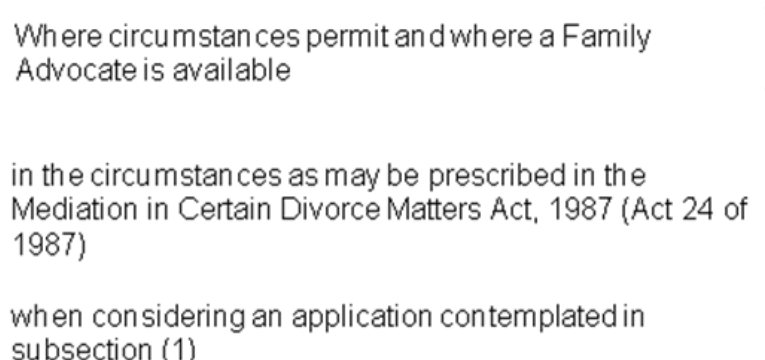

by a Family Advocate, contemplated in the Mediation in Certain Divorce Matters Act, 1987, in whose area of jurisdiction that court is

with regard to the welfare of any minor or dependent child affected by the proceedings in question

An analysis of this kind assists the legal translator to identify the intended meaning of the source text and to approach the translation task systematically. In addition, this method ensures that the translator preserves the letter of the law. In carrying out the analysis, the translator can also identify terminological gaps in the target language. During the process of separating the main provisionary clause from the qualifications, the translator simultaneously attends to problematic lexical items for which translation equivalents must be found, before she/he begins with the actual translation task. After terminological problems have been researched and solutions have been found, the translator starts by translating the main provisionary clause into the target language. She/he then translates the qualifications individually. Once the qualifications have been rendered in the target language, they are inserted at the correct syntactical positions in the main provisionary clause, in keeping with the syntactical organisation and following the rules of word order of the target language. Following this approach, the translation of section 5(1A) into Afrikaans is demonstrated below.

- Main provisionary clause: 'n hof kan 'n ondersoek laat instel

- Qualification 1: waar omstandighede dit toelaat en waar 'n gesinsadvokaat beskikbaar is 
- Qualification 2: in die omstandighede soos in die Wet op Bemiddeling in Sekere Egskeidingsaangeleenthede, 1987 (Wet No. 24 van 1987), voorgeskryf

- Qualification 3: wanneer 'n aansoek beoog in subartikel (1) oorweeg word

- Qualification 4: deur 'n gesinsadvokaat, beoog in die Wet op Bemiddeling in Sekere Egskeidingsaangeleenthede, 1987 in wie se regsgebied daardie hof geleë is

- Qualification 5: met betrekking tot die welsyn van enige minderjarige of afhanklike kind wat deur die betrokke verrigtings geraak word

- Qualification 6: waarop die bepalings van daardie Wet van toepassing is met die nodige veranderings soos vereis deur die samehang.

As indicated above, after the main provisionary clause and the qualifications have been rendered in the target language, the translator must bring about the necessary adjustments and inversions to adhere to the syntactical organisation and word order rules of Afrikaans:

(1A) Waar omstandighede dit toelaat en waar 'n gesinsadvokaat beskikbaar is, kan 'n hof, in die omstandighede soos in die Wet op Bemiddeling in Sekere Egskeidingsaangeleenthede, 1987 (Wet №. 24 van 1987), voorgeskryf, 'n aansoek beoog in subartikel (1) oorweeg, 'n ondersoek laat instel deur 'n gesinsadvokaat, beoog in die Wet op Bemiddeling in Sekere Egskeidingsaangeleenthede, 1987, in wie se regsgebied daardie hof geleë is, met betrekking tot die welsyn van enige minderjarige of afhanklike kind wat deur die betrokke verrigtings geraak word, waarop die bepalings van daardie Wet van toepassing is met die nodige veranderings soos vereis deur die samehang.

\section{Conclusion}

Legal translation is a complex and highly specialised activity that has received little or no attention in discourses and debates in translation theory in South Africa to date. The creation of new positions for legislative language practitioners in the Department of Justice and Constitutional Development places the practice of legal translation in the spotlight. Although this development is a welcome step that could transform the current practice of making legislation and 
other important government documents available in English only, and that could promote and develop the African languages, the market is not yet in a position to supply experienced legal translators with training in both language and the law.

It is imperative for all role-players and stakeholders to open the debate and to discuss and explore all aspects pertaining to the training of legal translators. These include government departments and state organs such as the Department of Justice and Constitutional Development, the Department of Arts and Culture, National Parliament, translation associations and agencies, and tertiary institutions and other institutions of higher learning. Tertiary institutions must respond to the current inadequacies in the training of translators by redesigning current qualifications and courses to include training in both disciplines, namely language and law. The nature and extent of the legal training must be carefully investigated to identify those aspects of the law that need to be incorporated into the training of legal translators. To achieve this, the debate needs to be extended also to include law faculties, since their inputs will be invaluable and highly relevant.

\section{List of references}

ALCARAZ VARÓ, E. \& HUGHES, B. 2002. Legal translation explained. Manchester: St. Jerome Publishing.

ASENSIO, R.M. 2003. Translating official documents. Manchester: St. Jerome Publishing.

BEAUPRÉ, M. 1987. La traduction juridique. Les cahiers de droit, 28(4):735745.

BEDNAREK, G. 2009. Translation of the European arrest warrant in the light of intercultural communication. Investigationes linguisticae, 17:84-99.

BHATIA, V.K. 1983a. An applied discourse analysis of English legislative writing. Birmingham: The University of Aston.

BHATIA, V.K. 1983b. Simplification v. easification - the case of legal texts. Applied linguistics, 4(1):42-54.

BHATIA, V.K. 1993. Analysing genre: language use in professional settings. London: Longman.

BHATIA, V. 1994. Cognitive structuring in legislative provisions. (In Gibbons, J., ed. Language and the law. London: Longman. p. 136-155.)

CAO, D. 2007. Translating law. Clevedon: Multilingual Matters.

DEPARTMENT OF JUSTICE AND CONSTITUTIONAL DEVELOPMENT. 2009. Departmental Circular, 18 December.

DoJ\&CD

see DEPARTMENT OF JUSTICE AND CONSTITUTIONAL DEVELOPMENT

GARZONE, G. 2000. Legal translation and functionalist approaches: a contradiction in terms? http://www.tradulex.org/Actes2000/Garzone.pdf Date of access: 28 Oct. 2009. 
GÉMAR, J-C. 1995. Traduire ou l'art d'interpréter, fonctions, statut et esthétique de la traduction. Tome 1: Principles. Saint-Nicolas: Presses de I' Université du Québec.

HJORT-PEDERSEN, M. \& FABER, D. 2005. Legal translation training and recognition of information needs. $L S P$ \& Professional communication, 5(1):42-53.

KENNEDY, R. 2000. Much ado about nothing: problems in the legal translation industry. Temple international \& comparative law journal, 14(2):423-444.

LLOPIS, M.A.O. 2007. The untranslatability of law? European journal of English studies, 11(1):17-28.

NEWMARK, P. 1981. Approaches to translation. London: Pergamon.

NORD, C. 1997. Translating as a purposeful activity. Manchester: St. Jerome.

POMMER, S.E. 2008. No creativity in legal translation? Babel, 54(4):355-368.

OBENAUS, G. 1995. The legal translator as information broker. (In Morris, M., ed. Translation and the law. Amsterdam: John Benjamins. p. 247-259.)

RAYAR, L. 1990. Law and language - postgraduate training of legal translators. Proceedings of the 12th World Congress of FIT, Belgrade. p. 643-646.

REK-HARROP, J.J. 2010. Polish and English translation of jurilinguistic discourse: key aspects and problem areas in the translation of certain forms of legal contracts in terms of terminology transfer between two different legal systems: Polish and English. http://www.harroptranslations. com/ Date of access: 13 Jul. 2010; and http://www.docstoc.com/docs/ DownloadDoc.aspx? doc_id=6337519\&ref_url= Date of access: 13 Jul. 2010.

ROTMAN, E. 1995-1996. The inherent problems of legal translation: theoretical aspects. Indiana international \& comparative law review, 6(1):187-196.

ŠARČEVIĆ, S. 1997. New approach to legal translation. The Hague: Kluwer Law International.

ŠARČEVIĆ, S. 2000. Legal translation and translation theory: a receiveroriented approach. http://www.tradulex.org/Actes2000/sarcevic.pdf Date of access: 25 Nov. 2009.

SCHWARZ, H. 1977. Legal and administrative language. Babel, 23(1):19-22.

SCJROTH, P.W. 1986. Legal translation. American journal of comparative law (supplement), 34:47-65.

SOUTH AFRICA. 1998. Domestic Violence Act, 1998 (Act 116 of 1998). Pretoria: Government Printer.

SOUTH AFRICA. Ministry of Finance. 1996. Government's position on community-based savings schemes. http://www.info.gov.za/speeches/1996/ j170w881.htm Date of access: 2 Mar. 2010.

VARNEY, J. 2009. From hermeneutics to the translation classroom: current perspectives on effective learning. Translation \& interpreting, 1(1):27-43.

WHITE, J.B. 1990. Justice as translation: an essay in cultural and legal criticism. Chicago: University of Chicago Press.

\section{Cases}

Lourens v President van die Republiek van Suid Afrika en Andere (49807/09) [2010] ZAGPPHC 19 (16 March 2010). http://www.saflii.org/za/cases/ ZAGPPHC/2010/19html Date of access: 17 June 2010. 


\section{Key concepts:}

legal translation training rhetorical structuring source text analysis translation competence

Kernbegrippe:

bronteksontleding regsvertaling, opleiding in retoriese strukturering vertaalbevoegdheid 
